\title{
Cooperation Formats of China and Europe: Synergies and Divergences
}

\author{
Inna Šteinbuka \\ University of Latvia \\ Aspazijas bulv 28, \\ Riga LV-1050, Latvia \\ E-mail: Inna.Steinbuka@ec.europa.eu \\ Tatyana Muravska \\ University of Latvia \\ Rainaa bulvaris 19 , \\ Riga LV-1586, Latvia \\ E-mail: Tatjana.Muravska@lu.Iv \\ Andris Kuznieks \\ University of Latvia \\ Aspazijas bulv 28, \\ Riga LV-1050, Latvia \\ E-mail: Andris.Kuznieks@ec.europa.eu
}

Abstract: This contribution articulates the synergies and divergences of the various formats of cooperation between China and the European countries. The EU and China have a strong interest in each other's flagship initiatives, namely the Investment Plan for Europe, and the One Belt, One Road Initiative (Silk Road Economic Belt and 21st-Century Maritime Silk Road). The authors argue that there are certain synergies between these initiatives. Furthermore, the new initiative EU-China Connectivity Platform is aimed to explore these synergies. The authors explore the recent developments in the EU-China investments, trade cooperation and the challenges of the ever-growing CEEC-China partnership in different formats, including the new platform of 16+1. The authors examine these implications in relation to the need to expand and adapt the content and approach of the EU-China Bilateral Investment agreement. The 
article concludes that the CEEC-China relation does not go against the EU; moreover, neither the CEE countries nor China have any motivation to try to weaken the EU.

Keywords: Bilateral investment agreement, CEEC economic integration, EU, trade and investment

\section{Introduction}

Historically, EU-China relations have focused to a large extent on trade in goods, and recently trade in services has also been growing rapidly. Trade in services is a relatively new development as compared with trade in goods. Contemporary EU-China initiatives and new cooperation formats have taken place in a difficult geo-economic situation and climate shaped by the impact of the economic crisis, Brexit and the US elections will have further repercussions to the EU-China relations also in the light of uncertainties regarding the TransPacific Partnership Agreement (TPP) and the Transatlantic Trade and Investment Partnership (TTIP). This could subsequently lead to a further increase of China's role in the global arena-including trade and investments.

The field of investments is still seen as holding a vast untapped potential for European and Chinese economies. The article explores the recent developments in the EU-China investments and trade cooperation and the challenges of the ever-growing CEEC-China partnership in different formats, including the new platform of $16+1$. While this new platform is still a 'work in progress', it has attracted increasing attention for supposedly affecting the united stance of the EU in the conduct of its foreign policy. In this article the rationale of each of the three sides - China, the EU and, more specifically, Central and Eastern European countries (CEEC) - will be analysed. It is argued that there is nothing substantive in this relation which would go against the EU; moreover, neither the CEE countries nor China have any motivation to try to weaken the EU. The article also articulates the synergies and divergences of the various formats of cooperation between China and the European countries. 


\section{EU-China trade and investments}

The EU and China are two of the biggest traders in the world. China is now the EU's second trading partner behind the United States, and the EU is China's main trading partner. EU-China trade has increased dramatically in recent years; for most trade items they are increasingly competitive (Fig. 1).

Figure 1. Development of EU exports and imports of goods with China, 2005-2015 (billion euros)

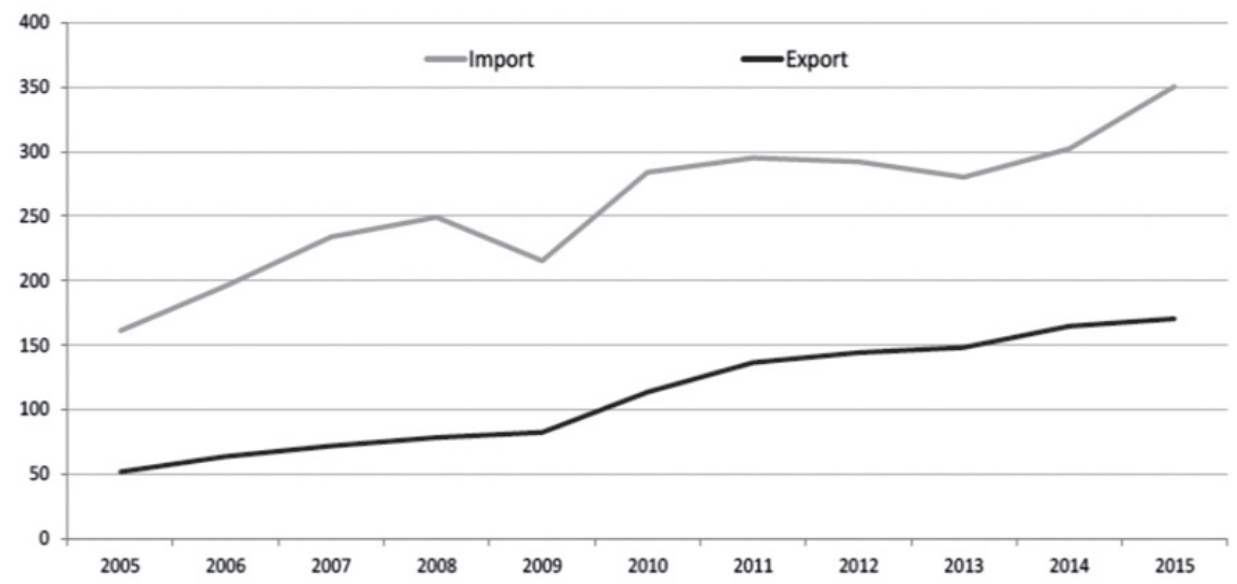

Source: Eurostat, 2016

China and Europe now trade well over 1 billion euros a day (EC DG Trade, 2016). The EU imports from China are dominated by industrial and consumer goods: machinery and equipment, footwear and clothing, furniture, and toys. EU exports to China are concentrated on machinery and equipment, motor vehicles, aircraft, and chemicals. According to the DG Trade of the European Commission (EC, 2016), the year 2015 has been marked by record trade deficit in goods worth of 180 billion euros, but record surplus in services (Fig. 2).

The EU is committed to widen trading relations with China. However, the EU wants to ensure that China trades fairly, respects intellectual property rights and meets its WTO obligations.

The 2008 financial crisis in Europe, and the subsequent (and still ongoing) debt crisis which hit the continent in 2010, has caused European investors to hold on tightly to their wallets. Europe today does not have a cash problem; it has a 
Figure 2. Development of EU exports and imports of services with China, 2010-2015 (billion euros)

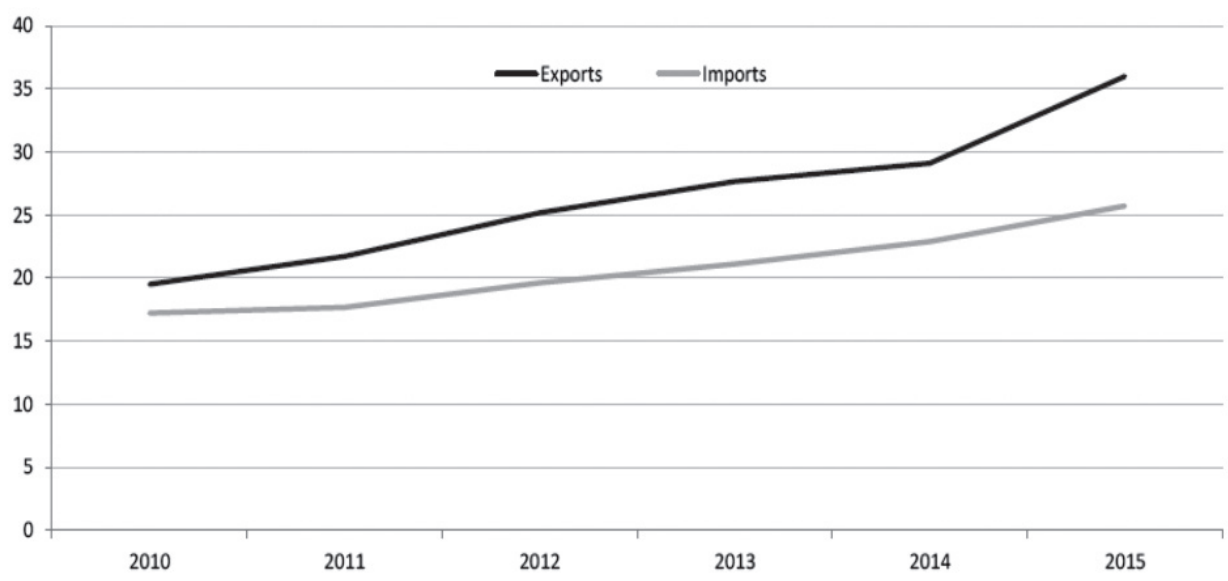

Source: Eurostat, 2016

liquidity problem. Businesses lack the confidence to spend the money they have. On the other side of the world, China is flush with cash from its economic boom. Chinese investors have stepped into the European investment void, buying properties, industries and financial assets (Fig. 3). China's outbound foreign direct investment (OFDI) has grown exponentially in recent years and hit a new record high of 20 billion euros in 2015, illustrating China's potential to become an important source of capital for Europe.

The 'Big 3'includes France, Germany and the UK; 'Benelux' includes Belgium, Netherlands and Luxembourg; 'Eastern Europe' includes Austria, Bulgaria, Czech Republic, Hungary, Poland, Romania and Slovakia; 'Southern Europe' includes Croatia, Cyprus, Greece, Italy, Malta, Portugal, Slovenia and Spain; 'Northern Europe' includes Estonia, Denmark, Finland, Ireland, Latvia and Sweden.

Investment flows show vast untapped potential, especially when taking into account the size of the respective economies. China accounts for just $2-3 \%$ of overall European investments abroad, whereas Chinese investments in Europe are rising, but from an even lower base while investments from the EU in China amount to a mere $5 \%$ of European investments abroad and only a fraction of the overall trade volume. In turn, foreign direct investment (FDI) from China represents less than $3 \%$ of the total FDI inflow into the EU (Hanemann \& Huotari, 2016). At the same time, the competition among EU states for Chinese 
Figure 3. Chinese OFDI in the EU-28 by country group 2000-2015 (million euros)

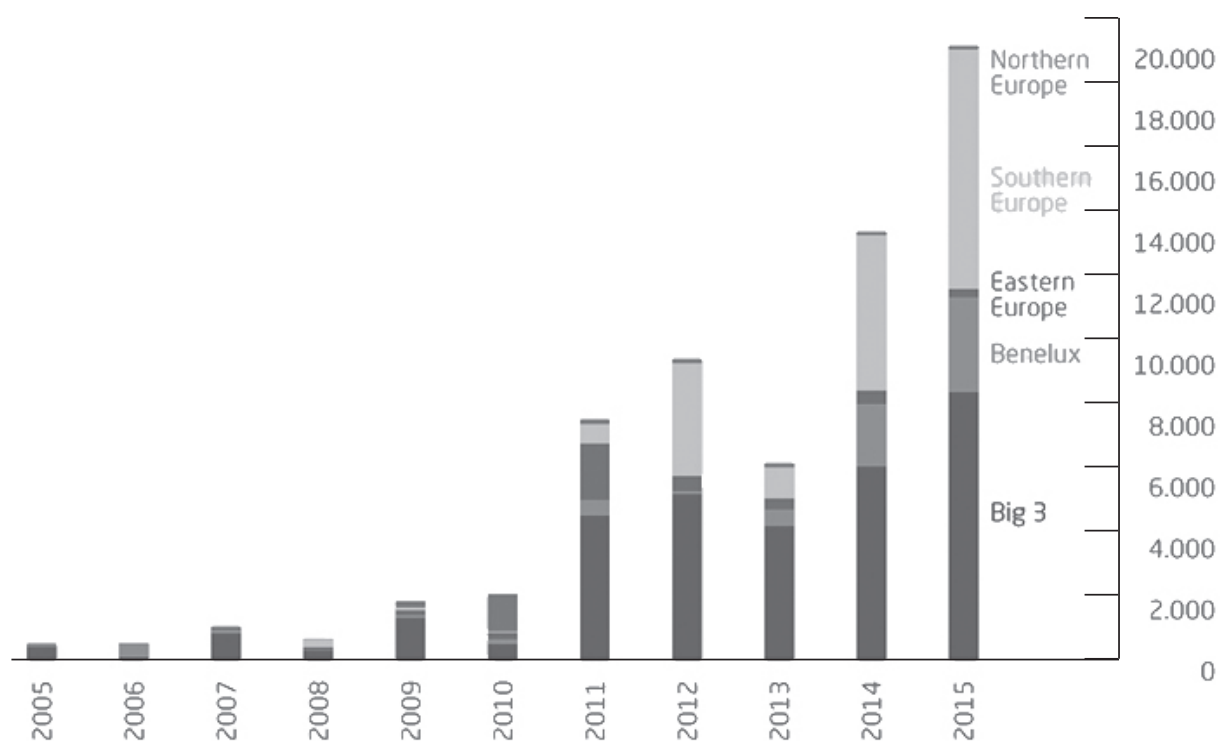

Source: Rhodium Group, 2016

capital has intensified, which weakens European leverage vis-à-vis China on important strategic questions. Moreover, investment patterns in 2015 further aggravate the existing economic concerns related to Chinese investment, most importantly the lack of equal market access for European companies in China and potential market distortions through state-owned and state-supported enterprises. Addressing those concerns now is critical as China expects to deploy an additional 1 trillion US dollars in OFDI in the coming five years in Europe and globally (Mission of China to the EU, 2016). Chinese investors have broadly followed the footsteps of other foreign investors in Europe by putting most of their investments in the wealthiest and largest European economies. The 'Big Three' (Germany, the UK, and France) have received a relatively constant figure of 4-8 billion euros over the last five years and they continued to be major targets in 2015. The big story of the past two years, however, is the sharp increase of Chinese OFDI in other parts of Europe. In 2015, Southern European economies accounted for almost half of all Chinese EU investment for the first time. High-profile 'flagship deals' (ChemChina's acquisition of Pirelli, Wanda's investment in Atletico Madrid, and Haitong's acquisition of Banco Espirito Santo's investment banking business) have put China in the role of a significant investor in those economies, amid otherwise sluggish FDI inflows. Investments 
in the Benelux countries also increased markedly in the past two years and pending projects could further boost Chinese presence in Eastern Europe if they materialise (Mission of China to the EU, 2016). The broader geographic dispersion of Chinese OFDI across Europe has increased competition between EU states for Chinese investment (Fig. 4).

Figure 4. Chinese FDI in the EU-28 in 2000-2015 (million euros)

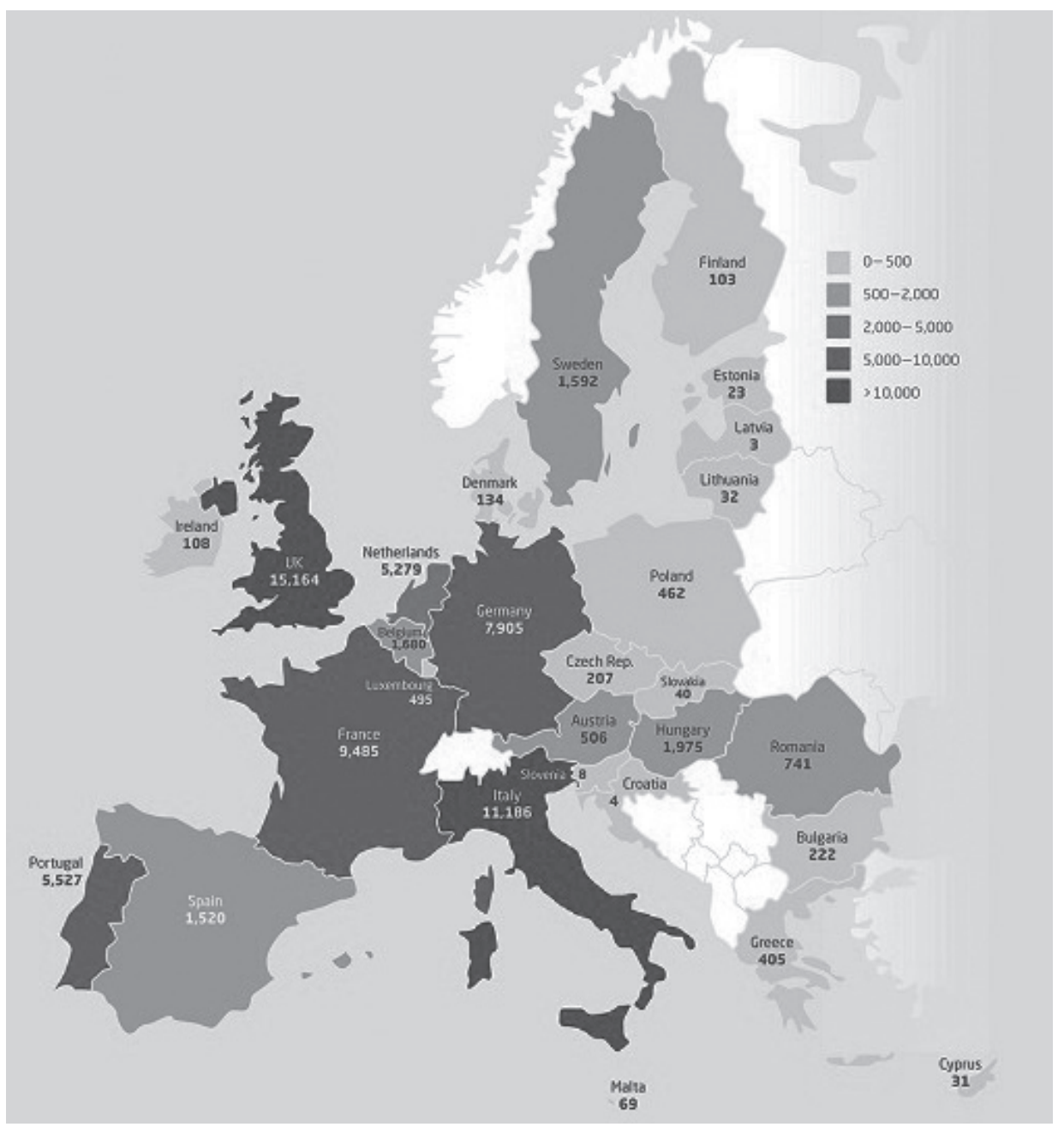

Source: Rhodium Group, 2016 
In 2015, virtually every EU Member State (MS) has sought high-level exchanges with China to strengthen bilateral investment and China is increasingly able to use the promise of capital as a carrot for other foreign policy goals. Greater capital flows, for example, remain the core driver of the rapidly evolving ' $16+1$ ' relationship between China and Central and Eastern European economies. Another example is the UK, where a flurry of high-profile investments has contributed to a visible shift in the UK's China policy. This race for Chinese investment is also contributing to a division between European economies over important economic policy decisions, most recently whether the EU should grant China Market Economy Status or if the EU should enter negotiations over a potential free trade agreement with China.

In addition to the anticipated economic gains from increased investments within various formats, European policymakers and businesses alike have placed high hopes in the conclusion of the bilateral investment agreement (BIA). In January 2016, representatives of the European Commission and the Chinese Ministry of Commerce met in Beijing for the ninth round of negotiations over the BIA between the EU and China. Negotiations over the BIA were initiated after the eurozone crisis erupted in 2008. The need for liquidity in European countries served as an impetus to enhance the possibilities of acquiring investments from outside Europe, while China pursues secure and predictable environments for its investments. The EU-China BIA is one of the priorities of the EU's new trade and investment strategy 'Trade for All' (Ewert, 2016), as a means to deepen relations with China. According to optimistic estimates, the negotiations could be concluded in 2017.

\section{Flagship initiatives to foster EU-China investment cooperation}

The EU and China have a strong interest in each other's flagship initiatives, namely the Investment Plan for Europe, and the Belt and Road initiative (Silk Road Economic Belt and 21st-Century Maritime Silk Road). We argue that there are certain synergies between these initiatives (Fig. 5).

Furthermore, the new initiative EU-China Connectivity Platform is aimed to explore these synergies. 
Figure 5. The EU-China cooperation: when geopolitical meets geoeconomics

- The EU's Strategic Investment Plan (Juncker Plan)

- The European Fund for Strategic Investments (EFSI)
- The One Belt One Road (OBOR) initiative

- The Silk Road Fund

- The Asian Infrastructure Investment Bank (AIIB)

\section{THE EU - CHINA BILATERAL INVESTMENT AGREEMENT}

Source: European Economic and Social Committee, 2016

\subsection{Investment Plan for Europe}

The idea behind the European Fund for Strategic Investments (EFSI) is that the public money will unlock the money from hesitant private investors in Europe and beyond. One could argue that the Chinese are more inclined to find Europe an attractive investment than are European investors. Chinese Premier Li Keqiang announced at the EU-China summit that China stands ready to dock with the EU's investment plan and make infrastructure investments (Mission of China to the EU, 2016). Specific figure on China's investment intentions has not been mentioned, although media reports have speculated that Beijing could invest between 5 and 10 billion euros in the EFSI, the EU's guarantee scheme to back risky projects in the EU. EU officials and Chinese authorities are examining what instruments could be used to channel the investment. The European Investment Bank (EIB) has set up a working group with the task to identify concrete modalities for joint EU-China cooperation on the Investment Plan for Europe. The group, which includes experts from China's Silk Road Fund, the Commission, and the EIB, will explore areas and opportunities for co-financing and participation from the Chinese side (Valero, 2016).

China's investment in the EU has sparked controversy in the past. In Greece, Chinese company COSCO was blamed for paying a fraction of European salaries and for not respecting European rights, according to the longshoreman's union (Valero, 2016). Elsewhere, Chinese labourers have been brought in to work on 
massive infrastructure projects, calling into question whether its involvement would create additional jobs for Europeans, as the investment plan aims to do.

The UK obtained financial support from China to construct a nuclear plant in Hinkley. In return for a 2 billion pounds loan guarantee, the UK will allow Chinese companies to build an additional nuclear plant in Bradwell, Essex.

The GMB union, which represents nuclear workers, said linking that deal to a reactor at Bradwell would be a "betrayal" of British workers. Brian Strutton, GMB National Secretary for Energy, said that "Chinese nuclear technology is unproven, and no UK government should even consider allowing it to be used in a new nuclear power station 60 miles from London" (Valero, 2016).

However, referring to Fraser Cameron, director of the EU-Asia centre in Brussels, China's contribution to the new investment fund represents a "winwin situation" for both partners (Valero, 2016). While Beijing wants to bolster its soft power in Europe, and gain European support on issues such as the reform of the IMF and the World Bank, China is also looking for large-scale projects to invest in that represent good business opportunities, in particular, high-speed trains and nuclear power plants.

\subsection{China's Belt and Road initiative}

The figures speak for themselves- $55 \%$ of the world's GDP, $70 \%$ of the world's population and $75 \%$ of energy resources are concentrated in the region covered by the OBOR initiative. With a planned overall financial commitment of around 1,400 billion euros, the strategic objective of this initiative is to reinforce China's role in global relations and step up its economic and trade relationships with the 65 countries also involved through transport and logistics infrastructure projects (Palmieri \& Celi, 2016).

The Juncker Plan and China's Belt and Road initiative are symmetrical. This strategy, which was unveiled in 2013, is focused on connecting the countries of Eurasia and the wider world through improved infrastructure networks, investment projects and cultural exchanges. The initiative has a land and a sea component, known respectively as the Silk Road Economic Belt and the 21st-Century Maritime Silk Road. Unlike the original Silk Road, however, the new project is not predominantly about transportation infrastructure but about economic integration. It attempts to create a set of political and institutional tools with which China can start to reorganise global value chains and stamp its imprint on the rules governing the global economy. 
The initiative is aimed at encouraging the countries along the Belt and Road to achieve economic policy coordination and carry out broader and more in-depth regional cooperation, and jointly create an open, inclusive and balanced regional economic cooperation architecture. In June 2015, China and Hungary signed a memorandum of understanding on further cooperation under the framework of the Belt and Road initiative. It is the first initiative document China has signed with a European country. China will work together with Hungary to step up the modernisation of the Budapest-Belgrade railroad, the construction of a ChinaEurope land-sea express line and completion of other major infrastructure projects (Gambrella, 2016). Both the Belt and Road initiative and the Juncker Plan will be primarily focused on infrastructure and cross-border connections. The plan is for 'Silk Road' infrastructure projects to extend all the way to Budapest, where they could link up with EU infrastructure projects funded by the Juncker Plan.

\section{Figure 6. The Belt and Road Initiative map}

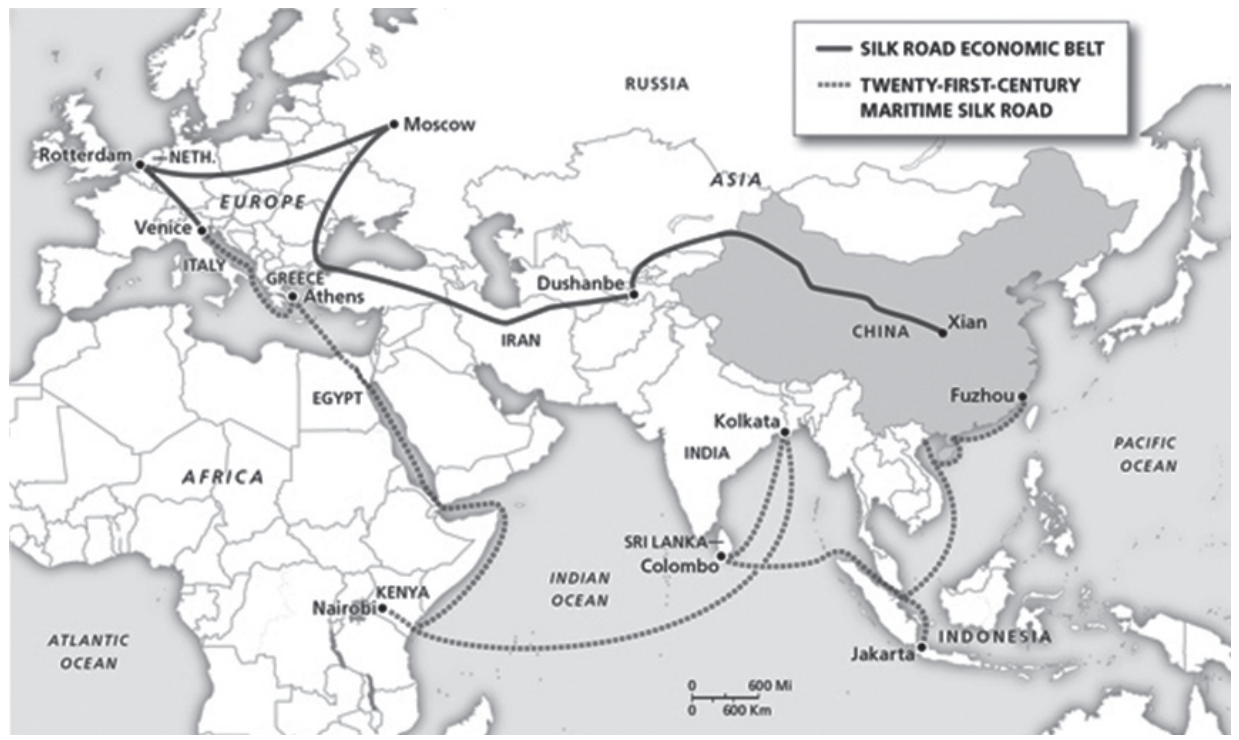

Source: Xinhua, 2015

The interest of Chinese businesses in investing in the European market is currently intense. Last year non-financial foreign direct investment from China to the EU was almost 10 billion dollars, exceeding FDI from the EU to China for the first time (Macaes, 2016). It is not just the lack of intra-European investment that is attracting Chinese businesses. Europe's regulatory environment also makes it an attractive destination. 


\subsection{EU-China Connectivity Platform}

The willingness of the EU and China to explore synergy between the two development strategies lead to establishing the EU-China Connectivity Platform as a vehicle to connect the Eurasian continent through a physical and digital network. The network would enable the flow of trade, investment and peopleto-people contact (Turcsányi, 2014). According to the EU strategy, cooperation on digital economy should harness growth through open markets, common standards and joint research on the basis of reciprocity in areas such as $5 \mathrm{G}$ mobile communications and the internet of things (EC, 2015).

With the EU's know-how and mature legislation system, and China's huge market needs and fast-moving innovation on advanced technology, the EU and China are natural partners, The Connectivity Platform would provide visibility on investment opportunities along the Silk Road to interested investors and other parties, as well as to provide a level playing field for investors and relevant business on both sides. Some of these projects might be suitable for financing by EU resources (including EFSI) and/or Chinese funds (such as Silk Road Fund). The EIB would contribute to the work of the Platform so as to explore opportunities for co-financing infrastructure links between the EU and China, in the framework of EIB external mandates.

The EU wants a China that is economically more open and stable, with significantly improved market access for foreign companies. A company like Alibaba could play a key role in this process by providing the EU companiesand in particular small and medium-sized enterprises - a platform to reach Chinese undertakings and consumers. In this context, deepening cooperation on customs and trade facilitation would be appropriate to boost e-commerce between the EU and China. At the same time, the EU establishes a common minimum definition of what constitutes critical national infrastructure in the context of inward investment, to provide legal certainty and promote investment, something it has done, for example, with the countries of Eastern Partnership (Kerikmäe \& Chochia, 2016). 


\subsection{Investment banking for infrastructure building and strategic development in Asia}

The new international development bank was launched in early 2016. Although it is seen as a rival to the US-led World Bank, many countries have agreed to join the Asian Infrastructure Investment Bank (AIIB) in recognition of China's growing economic clout. So far 13 EU Member States (Austria, Denmark, Finland, France, Germany, Italy, Malta, Netherlands, Poland, Portugal, Spain, Sweden, UK) have joined the Asian Infrastructure Investment Bank, which is considerable participation, at the same time indicating that not all EU Member States have the same stance on the issue of joining the AIIB. The prospects for other EU Member States to join are not clear and depend very much on countries themselves. It seems that Beijing seeks to change the unwritten rules of global development finance. The AIIB is expected to lend 10 to 15 billion dollars a year for the first five or six years and has started its operations in the second quarter of 2016 (Palmieri \& Celi, 2016). The opening of the Asian Infrastructure Investment Bank (AIIB) is part of China's vision of strategic development, which aims to achieve the "two centenary goals".

For China, the new bank is fundamental for reinforcing its international position outside the Post Bretton Woods System. The initiative is intended to support the introduction of a multipolar financial and currency system able to offer alternative solutions to the monopoly of the dollar.

Unlike other, similar initiatives, such as the New Development Bank (NDB), which was set up by the BRICS, China has asked other countries to be founding members of the AIIB without any prerequisites. While for Asian countries this provides an opportunity to take actively part in the decision-making process on investments which will reduce their infrastructure deficit, for European countries joining the AIIB is seen as an opportunity to tap into the major infrastructure market which will be developing in Asia in the coming years by winning tenders and subcontracting contracts for their own companies. 


\section{Framework 16+1: developments and prospects}

\subsection{New opportunity}

Despite the large volume of trade, mutual direct investment is still relatively low, according to the European Community with just over 2\% of EU FDI in China (EC, 2016).

For years, European companies sought to benefit from cheap labour by building factories in China, but today that trend is reversing. Chinese investors are now eyeing Eastern Europe and the Mediterranean, where the eurozone crisis has pushed labour costs down and created hunger for foreign investment.

The CEE EU countries are not at the forefront of EU relations with third countries. Since the fall of the communist regimes their foreign policies have been almost predominantly oriented towards the EU. Now these countries are interested in developing relations with China in the CEEC-China $16+1$ cooperation format, which raises issues in relation to the EU common foreign trade policy. CEECChina $16+1$ cooperation format is driven by trade promotion and investment, thus serving as a basis for enhancing the bilateral cooperation between China and CEEC, which the Chinese media describe as a "golden opportunity". The format has included a wide range of activities and in such sectors as cooperation and connectivity, economic and financial issues, agriculture and forestry, science, technology and health, people-to-people contacts and cultural exchanges, cooperation at the local governmental level (LIIA, 2016).

The format, which held its first summit in 2012 in Warsaw, Poland, brought together leaders from China and 16 CEEC: Albania, Bosnia and Herzegovina, Bulgaria, Croatia, Czech Republic, Estonia, Hungary, Latvia, Lithuania, Macedonia, Montenegro, Poland, Romania, Serbia, Slovakia, and Slovenia.

The situation of bilateral cooperation between China and CEEC is rather diverse with very different levels of progress and engagement achieved. But the questions remain: where there is this "golden opportunity" and whether there are any risks when it comes to the synergies between the EU-China relations and the $16+1$ cooperation? Since the opening up of the $16+1$ platform, relations between China and the CEEC have been increasingly attracting attention around Europe, for supposedly affecting the united position of the EU, which is against the EU good practices to develop a separate institutionalised relation with a third state. The rationale for this relatively new relationship should be seen from three perspectives - China as the initiator of the platform; the involved CEEC as the 
main beneficiaries; and the EU as the 'mother' unit partly encompassing the CEE region. Scholars argue (Turcsányi, 2014) that statements about a dividing line are improper and these accusations are based largely on false presumptions or potential future problems. On the other hand, the approach of the Western European countries may in fact point to the EU's internal problems. China is exploring new ways to expand its exports, looking for secure and reliable channels and hopes that building up better relations with the CEEC, most of whom are also EU MS, can help push forward its overall relations with the EU. In this context, the $16+1$ format represents for China its complimentary "bridge to Europe". The CEE region is becoming a distinct link within China's new Silk Road, which will more directly connect East Asia to Europe. Logistically CEEC will play a crucial role in making sure China's Silk Road Economic Belt reaches its final destination-Western Europe.

\subsection{Achievements to date}

The format has made CEE important in terms of Chinese foreign policy. Since the summits in Belgrade and Riga, the role of the Balkans and Baltic states in Chinese policy towards Europe has increased. Miscellaneous meetings under the $16+1$ format contributed to the intensification of political dialogue on the lower level (for example, that of ministers and local authorities) and peopleto-people exchanges. Moreover, the status of Central Europe within the region and in the EU has been raised. The CEE countries showed that they are able to establish their own formula for cooperation with China, and to pursue an active policy towards non-European great powers. Another result is the rise of interest of potential investors in countries, which hosted the $16+1$ summits. For example, Serbia and Romania recorded increased interest from potential investors, not only from China but also from Korea and Japan. As far as economic cooperation is concerned, discrepancies between EU and non-EU members are noticeable, especially in terms of investments and infrastructural projects. They are located mainly in the non-EU countries, which indicate the weakness of Chinese financial instruments that are not adapted to the needs of all countries. The Chinese credit line is being used, for example, in Bosnia and Herzegovina for the construction of a thermal power plant in Stanari, in Macedonia for building highways, and in Serbia for a Belgrade bypass. Credit from China-based Exim Bank is being used to build a new thermal power plant unit in Kostolac. Similar credit was also utilised to build a bridge over the Danube in Belgrade, which was officially opened in 2014 (Szczudlik, 2016). In terms of failures to date, there has been little progress with the high-speed Belgrade-to-Budapest railway, a 16+1 flagship project. Many agreements have 


\section{The Riga Summit}

The fifth CEEC-China 16+1 Summit took place in Riga on 4-6 November 2016; although it is seen as a great achievement by Latvian hosts, there was an overall impression that it was very much Chinese-driven event. Both the Latvian PM Kučinskis and the Chinese PM Li Keqiang emphasised the importance of EUChina cooperation and complementarity of the $16+1$ format. At the summit, China launched a 10 billion euro investment fund to finance projects in CEE (Ministry of Foreign Affairs of the Republic of Latvia, 2016); the fund is aiming to raise a total of 50 billion euros in project financing for sectors such as infrastructure, hightech manufacturing and consumer goods. While targeting the CEE region, it could extend to the rest of Europe and other areas, if relevant to China-CEE cooperation. It also has certain synergy with and well compliments the Investment Plan for Europe (Nikers, 2016).

The summit focussed on the logistics and development of new freight routes, symbolically, the first rail cars loaded with containers arrived in Riga from the Chinese city of Yiwu, carrying textiles, plumbing and household goods, the train travelled more than 11,000 kilometres across Russia to Riga in 16 days (Yiwu-ZabaikalskRiga).

It is evident that China is becoming an increasingly important trading partner for all three of the Baltic States, as their access to and interest in the Russia market has gradually eroded. Moreover, the Baltics' exports to China have been growing. Ten years ago, in 2006, Latvian exports to China accounted for only 10 million euros, while currently they have grown to more than 100 million euros (106.75 million US dollars). Latvian food exports to China, in particular, have found new niches thanks to the certification of a number of dairy and fish manufacturers. In addition, Latvian timber products, cosmetics and electrical equipment have also been making substantial inroads in China (Simurina, 2015). 
been signed but not implemented, and there are concerns that the 1.7 billion dollar line of credit extended by China may seriously increase Hungary's national debt. Furthermore, the European Commission has initiated preliminary infringement proceedings against Hungary. This is because the project assumes implementation by a consortium from Hungary and China (15\% and $85 \%$, respectively) based on an intergovernmental agreement (Szczudlik, 2016), but not through issuing tender procedures. In Riga the decision was made that the consortium will announce a tender and sign agreements with contractors. This means that the consortium itself will not be a project contractor, although the financial aspects have not changed and $85 \%$ of the project (Szczudlik, 2016) was expected to be financed with Chinese credit. Still, the level of Chinese investments is modest, while the trade deficit on the CEE side is increasing. China has not yet located manufacturing bases in Central Europe, an idea that it announced at previous summits. At the same time Chinese firms are increasingly investing in CEEC. These investments are quite a new phenomenon and still constitute a small share of China's total FDI in Europe (10\%), but since 2006 we have seen a growing influx of Chinese investments into the region, which is expected to increase further in the future (Fig. 7).

Figure 7. China's OFDI stock in Visegrad Countries, 2003-2012 (billion US dollars)

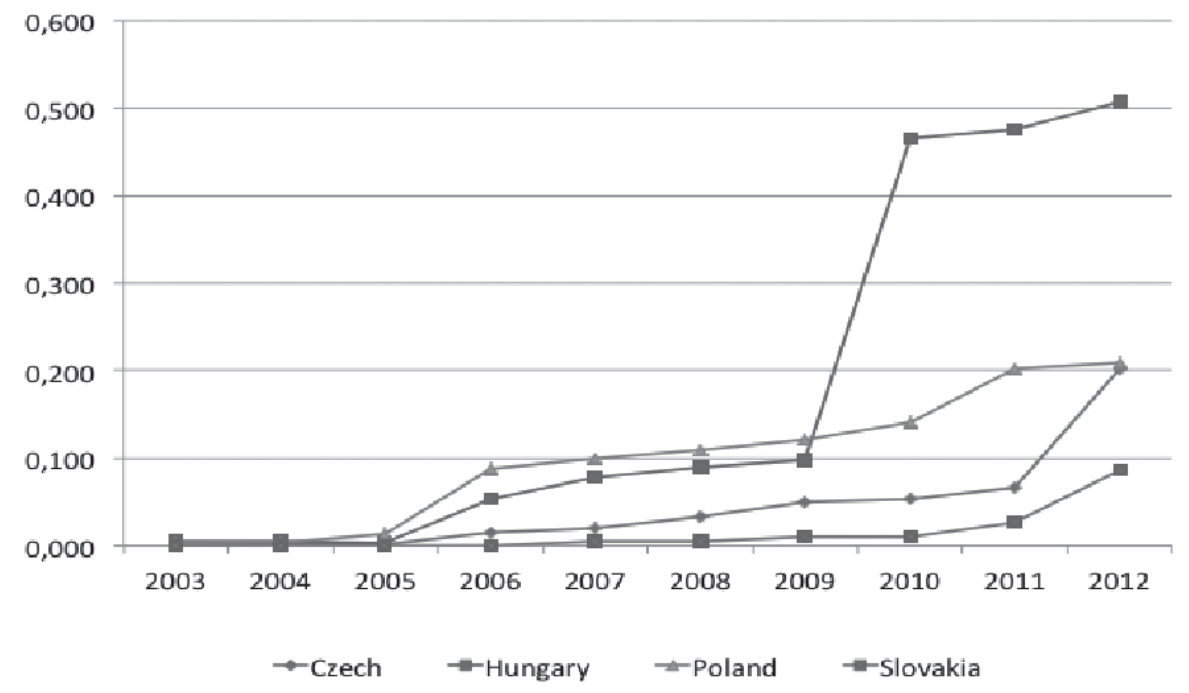

Source: CEIC, 2012; MOFCON 2013 


\subsection{Prospects}

China and the European countries will not abandon the $16+1$ format $-\mathrm{a}$ useful political instrument. One may expect an extension of the format, for example with other countries acting as observers. This assumption may be vindicated by the fact that China has recently been promoting the $16+1$ as "open". With more countries on board in the framework of $16+1$, China may highlight its rising international status and attract more allies for its own interests. At one 16+1 meeting in Ningbo, in June, Hungary openly declared support for granting China market economy status. It also supported China's position on the South China Sea issue, just before a ruling by the Court of Arbitration, and afterwards, with Croatia, was reluctant to adopt the EU statement about this issue. The decision to hold the next $16+1$ summit in Hungary might be perceived as appreciation for Viktor Orbán's pro-Chinese policy. It is worth mentioning that the Czech Republic was also interested in hosting the next summit (Szczudlik, 2016). For China, the $16+1$ remains a mechanism for gaining knowledge about the region, such as investment conditions and plans, important for the implementation of the Silk Road initiative.

The 16 countries will also use the format to indicate their own interests and strengthen bilateral relations with China. A good example is Latvia, which is greatly interested in transport in the northeastern part of Europe. Latvia sees opportunities for cooperation with China, following the deterioration of its relations with Russia after the imposition of sanctions that limited Russian trade in the ports of the Baltic States. The 16+1 format should serve as well for Poland (Szczudlik, 2016) as a complementary element for strengthening bilateral relations and the pursuit of Polish interests.

\section{Concluding remarks}

The analysis shows that there is high level of synergy between the EU-China and CEEC-China cooperation as both are based on the same objectives to boost trade and investment and to create jobs and growth. CEEC and China's ever growing cooperation should rather be seen as complementary to the efforts that are taken on the EU-China level. In addition, there are no major risks that could go against the EU; moreover, neither the CEE countries nor China have any motivation to try to weaken the EU. 
Chinese investments and trade cooperation and the challenges of evergrowing CEEC-China partnership in the different formats, including the new platform of $16+1$, are still a new platform a 'work in progress' and have attracted increasing attention for affecting the united position of the EU in its foreign policy.

In the last decade, bilateral relations between the EU and China have become a real "strategic partnership" in the areas of trade cooperation, environmental protection, innovation, research, education and international security. In the coming years, cooperation will become even stronger and more challenging. If these challenges are to become opportunities using a win-win approach, they must be based on the "reciprocity" principle.

While in China the framing and implementation of development policies is very much centrally coordinated, the EU is definitely weak when it comes to framing common political and economic strategies; in many cases, particularly regarding economic issues, the EU MS compete instead of cooperating, leaving individual enterprises to decide on strategies on how and where to invest. This dynamic could harm the economy of the majority of MS, particularly given that these challenges cannot be tackled effectively by individual national systems.

The need to reinforce EU action on the "European dimension" of OBOR is clear from the fact that under the 16+1 mechanism (12 of the 16 are EU Member States), cooperation is already underway between China and the CEE countries. This process should be properly managed for this dynamic not to lead to tension, damaging European cohesion and relations between the EU, its MS and between the countries themselves.

The absence of a clear and coordinated EU position on the AIIB has not allowed for the planning and implementation of a common strategy, which would certainly have been useful for harnessing the EU's interests to those of the individual MS. Given the pace of change and the considerable prospects for development of AIIB, the EU should support greater coordination at Member State level, partly with a view to shaping initiatives planned and implemented using a common approach which analyses all the abovementioned initiatives holistically. 
Inna Šteinbuka, currently head of the EC Representation in Riga (since September 2011) was director of Social and Information Society Statistics in Eurostat, European Commission in 2008-2011, and director of Economic and Regional Statistics in 2005-2008. From 20012005 she was chair of the Latvian Public Utilities Commission in charge of regulation of electricity, gas and telecommunication markets as well as railway and postal services. From 1999-2001, she was senior advisor to executive director at the International Monetary Fund in Washington DC. From 1991 to 1999, she was director of Economic Analyses and Fiscal Policy Department in the Latvian Ministry of Finance, and advisor to Minister of Finance. Mrs. Steinbuka is professor of economics at the Latvian University and member of the Latvian Academy of Sciences.

Tatyana Muravska is professor of regional and European integration studies at the University of Latvia (UL). Her research and publications have covered social and economic issues in the EU-12, including external cooperation with third countries. Since the beginning of the 1990s she has been involved in the process of developing European studies at the UL; she has been visiting professor in partner universities in Europe, Canada and India. She has held fellowships at a number of academic institutions in the EU and Canada. Since 2000 she is director of the Centre for European and Transition Studies, European studies master's programme, Doctoral School for European Integration and Baltic Sea Region Studies, academic coordinator of Jean Monnet Centre of Excellence and Jean Monnet Chair ad personam at the UL; President of Latvian European Community Studies Association. She has been involved in EU, World Bank, UNDP, CIDA research projects.

Andris Kuznieks is deputy head of the European Commission Representation in Latvia. He holds a master's degree in European Studies from the University of Latvia. His research and academic activities have been mainly focussed on EU regional policy. He is lecturer at the European Studies Programme, University of Latvia. He has expertise also in external cooperation with third countries especially Eastern Partnership and Central Asia. He has been the leading expert in EU funded projects in Kazakhstan, Georgia, Russia and Azerbaijan. 


\section{References}

CEIC (2012), CEIC Data's China Premium Database. Retrieved from https://www. ceicdata.com/ [accessed May 2017]

EC (2015), EU-China High Level Economic and Trade Dialogue, Beijing, 28 September 2015.

EC DGT (2016), China - main indicators, European Union Trade in Goods. Retrieved from http://trade.ec.europa.eu/doclib/docs/2006/september/tradoc_113366.pdf [accessed May 2017]

Eurostat (2016), Economic relations between China and the EU. Retrieved from http://ec.europa.eu/trade/policy/countries-and-regions/countries/china/ [accessed May 2017]

Ewert, I. (2016), Between High Hopes and Real Challenges, Security Policy Brief, Egmont Royal Institute for International Relations, no. 68, February 2016. Retrieved from http://www.egmontinstitute.be/wp-content/uploads/2016/02/ SPB68-Ewert.pdf [accessed May 2017]

(2015), “China's European Investment: Mission of China to the EU," Politico, 11 February 2015. Retrieved from http://www.politico.eu/sponsored-content/ chinas-european-investment/ [accessed May 2017]

Gambrella, L. (2016), 'EU needs forward-looking China plan,' Eureporter World, 3 August 2016. Retrieved from https://www.eureporter.co/world/2016/08/03/euneeds-forward-looking-china-plan/ [accessed May 2017]

Hanemann, T. \& Huotari, M. (2016), A New Record Year for Chinese Outbound Investment in Europe, Rhodium Group Report. Retrieved from http://rhg.com/ reports/a-new-record-year-for-chinese-outbound-investment-in-europe [accessed May 2017]

Kerikmäe, T. \& Chochia, A., eds. (2016), Political and Legal Perspectives of the EU Eastern Partnership Policy, Heidelberg, New York, etc.: Springer International Publishing.

LIIA (2016), 'Forum introduction,' International Forum of China and Central and Eastern European Countries: Enhanced Connectivity for Common Advancement, 4 November 2016, Latvian Institute of International Affairs.

Maçães, B. (2016), "China's Belt and Road: Destination Europe," Carnegie Europe, 9 November 2016. Retrieved from http://carnegieeurope.eu/2016/11/09/china-sbelt-and-road-destination-europe-pub-65075 [accessed May 2017]

Ministry of Foreign Affairs of the Republic of Latvia (2016), 'The meeting of Heads of Government of Central and Eastern European countries and China: Riga Declaration,' Cooperation between China and Central and Eastern European Countries, 10 November 2016. Retrieved from http://www.china-ceec.org/eng/ 
zyxw_4/t1414325.htm [accessed May 2017]

Montesano, F. S. \& Okano-Heijmans, M. (2016), "Economic Diplomacy in EU-China Relations: Why Europe Needs its Own 'OBOR',' Clingendael Policy Brief, June 2016, Netherlands Institute of International Relations.

NDRC (2015), 'Vision and Actions on Jointly Building Silk Road Economic Belt and 21st-Century Maritime Silk Road,' News release, National Development and Reform Commission of the People's Republic of China, 28 March 2015. Retrieved from at http://en.ndrc.gov.cn/newsrelease/201503/t20150330_669367. html [accessed May 2017]

Nikers, O. (2016), 'China and CEE Countries Push for Broader Economic Cooperation in Riga,' Eurasia Daily Monitor, vol. 13, no. 184. Retrieved from https://jamestown.org/program/china-cee-countries-push-broader-economiccooperation-riga/\#sthash.vkDAEQeA.dpuf [accessed May 2017]

Palmieri, S. \& Celi, M. (2016), Report on Infrastructure and Investment: the One Belt One Road Initiative and the launch of the Asian Infrastructure Investment Bank (AIIB), European Economic and Social Committee, 10 May 2016.

Simurina, J. (2015), China's Approach to the CEE-16, Europe China Research and Advice Network Short Policy Brief, 85. Retrieved from http://eeas.europa. eu/archives/docs/china/docs/division_ecran/ecran_is107_paper_85_chinas_ approach_to_the_cee-16_jurica_simurina_en.pdf [accessed May 2017]

Szczudlik, J. (2016), 'Prospects for China-CEE Relations in the 16+1 Format,' Bulletin Pism, no. 76 (926), 18 November 2016. Retrieved from https://www.pism.pl/ publications/bulletin/no-76-926 [accessed May 2017]

Turcsányi, R. (2014), 'Central and Eastern Europe's courtship with China: Trojan horse within the EU?' EU-Asia at a Glance. Retrieved from http://www.eias.org/wpcontent/uploads/2016/02/EU-Asia-at-a-glance-Richard-Turcsanyi-China-CEE. pdf [accessed May 2017]

Valero, J. (2016), 'Brussels clears way for China to pour billions into Juncker Plan,' Euractiv.com, 13 April 2016. Retrieved from https://www.euractiv.com/section/ innovation-industry/news/brussels-clears-way-for-china-to-pour-billions-intojuncker-plan/ [accessed May 2017]

Xinhua (2015), The Belt and Road Initiative map, Xinhua News Agency. 